TEME, г. XLI, бр. 2, април - јун 2017, стр. 337-354

Оригинални научни рад

DOI: $10.22190 /$ TEME1702337R

Примљено: 27. 10. 2015.

UDK 316.728:338.48-4

Ревидирана верзија: 25. 5. 2016.

Одобрено за штампу: 15. 6. 2017.

\title{
ПУТОВАЊЕ У ИНОСТРАНСТВО КАО ПРАКСА КУЛТУРНЕ ПОТРОШЫЕ У ДРУШТВУ СРБИЈЕ
}

\author{
Љубица М. Рајковић \\ Универзитет у Београду, Географски факултет, Београд, Србија \\ brljubica@yahoo.com
}

\begin{abstract}
Апстракт
Рад представља истраживање путовања у иностранство као праксе културне потрошње у друштву Србије. Анализиран је однос културне потрошње кроз путовање у иностранство и образовања, занимања и места боравка, који генеришу одређене културне праксе - путовање у иностранство грађана који користе услуге туристичких агенција у друштву Србије. Према становишту Бурдијеове (Bourdieu) теорије културне потрошње, класна припадност појединца и његове породице детерминишу културну потрошњу и задовољавање културних потреба, те путовање у иностранство добија изузетну важност у свакодневном животу доминантних структурних група. У друштву Србије као средишња оса што дели праксу културне потрошње међу становништвом које путује у иностранство појављују се димензије: занимање, образовање и место боравка. Тако, путовање у иностранство преко агенција, као културна форма у полупериферијском друштву, какво је друштво Србије, функционише као знак дистинкције која је отворена само вишим слојевима.

Анкетирање је обављено у периоду март-мај 2014. године у туристичким агенцијама у Београду, као и у градовима централне Србије. Узорак је састављен од испитаника из градских и сеоских насеља, укупно 613 јединица популације.
\end{abstract}

Кључне речи: културна потрошња, путовање у иностранство, дистинкција, Србија.

\section{TRAVEL ABROAD AS A FORM OF CULTURAL CONSUMPTION IN SERBIAN SOCIETY}

\begin{abstract}
The paper presents research on travelling abroad as a form of cultural consumption in the Serbian society and the motivation (interest) of consumers to participate in such tourism practice. The relation between cultural consumption and travel abroad of citizens who use services of travel agencies in Serbia was analysed through foreign travel, education, tourism interests and destinations that generate certain cultural practices. According to Bourdieu's view on the theory of cultural consumption, class affiliation of an individual and his/her family background determine cultural consumption and ways of satisfying his/her cultural needs, so travel abroad demonstrates exceptional importance in
\end{abstract}


daily life of the dominant structural groups. In the Serbia's society, the central axis that divides the practice of cultural consumption among its citizens that travel abroad is characterized by the following dimensions: occupation, education and the place of residence. Thus, foreign travel organized by travel agencies, as a cultural form in semiperipheral society, such as the Serbia's society, presents a mark of distinction that is affordable only to higher layers.

The survey was conducted in the period from March to May 2014 by the students of Tourism Department at the Faculty of Geography in Belgrade, as part of their compulsory practical work in Sociology of Tourism. The survey was conducted in travel agencies in Belgrade and in central Serbian towns, in accordance with their individual choices and availability of agencies. The sample was made up of respondents from urban and rural settlements, a total of 613 .

Key words: cultural consumption, travel abroad, distinction, Serbia.

\section{УВОД}

У овом истраживању разматрају се култура и туризам као пракса - туристичка пракса у форми путовања у иностранство. Култура којом се бавимо у овом раду јесте „догађање у свакодневном животу, које упознајемо кроз његова свакодневна испољавања; она није одвојена у засебну сферу, која је окружена ауром недодирљивости и страхопоштовањем" (Спасић, 2013: 12). Другим речима, у раду се не разматра култура уопште, већ облик културне праксе у форми путовања у иностранство, као вид „културе на делу” (Спасић, исто) у Србији данас.

Предмет проучавања јесте путовање у иностранство као облик туристичке потрошње и културне праксе. Ближе одређено, испитивање приватне културне рецепције грађана Србије који користе услуге туристичких агенција за партиципацију путовања у иностранство. Тако одређен предмет проучавања биће анализиран на основу података који су непосредно прикупљени у туристичким агенцијама, путем разговора са актерима путовања у иностранство.

Циљ истраживања је да се идентификују групе туриста које путују у иностранство, користећи услуге туристичких агенција и њихове културне потребе. Циљ је и да се одговори на питање шта људима значи путовање, коју врсту потреба задовољавају, учесталост путовања, те у којој мери путовање у иностранство преко агенција функционише као знак дистинкције, која је отворена вишим слојевима.

Путовањем у иностранство посредством туристичких агенција могу се задовољити културне, али и друге врсте потреба: 1. сроднички разлози за путовање (посета блиских рођака и пријатеља у иностранству); 2. економски разлози: повољне цене, јефтино, ниска цена аранжмана; 3. склапање пословних аранжмана и истраживања тржишта; 4. други разлози: здравствени, куповина робе и сл. У овом истраживању анализиран је значај путовања у иностранство за задово- 
љавање културних потреба - „туристичке потребе као културне потребе” (Драгићевић-Шешић, 1983; Божовић, 1992; Кошничар, 1999; Чолић, 2008). Културна партиципација подељена је на: а): културну рецепцију (потрошња) која се одвија кроз избор туристичких дестинација ради остваривања сазнајних потреба (откривање нових култура, егзотичних места, обилазак историјских споменика, верски разлози) и б) културну рецепцију ради остваривања рекреативних потреба (дружење, провод, забава).

Зашто се у овом раду путовање у иностранство схвата као облик културне потрошње? Путовање у инострансто није конвенционална културна пракса као што је одлазак у позориште, читање књига, већ се схвата као облик приватне културне партиципације, који има свој симболички аспект. Она доприноси друштвеној диференцијацији и хијерархији. Људи праве изборе, стратегије културног понашања. Путовање у иностранство одређено је као културна потреба у овом раду зато што се културне потребе у овој форми користе као основа за симболичко и социјално искључивање. Изабране дестинације имају наглашено место у конституисању осећања задовољства, постају статусни симболи и „симболички обрасци” (Спасић 2013: 14), али садрже и сазнајне, егзотичне, рекреативне елементе. Путовање не служи само да се у њему ужива већ да се утврде разлике и хијерархије између друштвених група. Функција путовања у иностранство јесте и бег, забава, комерцијални интереси, хедонизам, рекреација. Актери у овом облику културне потрошње траже интелектуално и духовно уздизање и конформизам.

Колико је нама познато, у Србији до сада нису рађене студије путовања у иностранство грађана, као облик културне и туристичке потрошње.Такође, мали је број домаћих аутора који су се бавили истраживањем културне потрошње. Једно од малог броја домаћих истраживања културне потрошње јесте студија Културне потребе, навике и укус грађана Србије и Македоније Предрага Цветичанина из 2007. године.

\section{ТЕОРИЈСКИ ПРИСТУП}

Теоријски оквир овог рада полази од теорија које повезују активности културне потрошње са друштвеним класама. Полази се од теоријских становишта Пјера Бурдијеа (Pierre Bourdieu, 2013, 2004, 1999, 1984, 1985) увођењем културне димензије у социолошка проучавања стратификације и класа; култура и културна потрошња доприносе репродукцији класног система у савременим друштвима, као и да између економских позиција (класа) и стилова живота (статусних група) постоји инваријантни однос: класе се појављују као статусне групе чији културно стратификовани укуси и добра легитимишу систем 
економске доминације. У Бурдијеовом учењу, култура је тесно повезана са друштвеним неједнакостима и борбама (Спасић 2013: 13).

Бурдије користи културне димензије у социолошка проучавања стратификације и класа и развија теорију о томе како култура и културна потрошња доприносе репродукцији класног система у савременим друштвима. Према Бурдијеу $(2013,2004)$, културне праксе врше класификаиију: уједињују и одвајају. Културне праксе су производ деловања одређених услова егзистенције, истовремено уједињују све оне који деле сличне услове живота и одваја их од оних са различитим егзистенцијалним условима. Културне праксе, кроз друштвену селекцију и кроз легитимацију друштвених разлика, доприносе репродукцији класне доминације. Према Бурдијеу, два основна организациона принципа друштва - укупни обим капитала и његова композиција - одређују структуру и промене културне потрошње, па и читав универзум животних стилова. Ево како је приказана структура и промене културне потрошње: „доминантну класу, која поседује велики обим капитала, карактерише 'укус слободе' - удаљеност живота ових класа од непосредног деловања економских и социјалних нужности. Буржоазија поседује економски капитал и преферира уметност коју карактерише порицање друштвеног света, хедонизам и лакоћа. Интелектуалци и уметници, који свој положај дугују поседовању културног капитала, противе се буржоаској склоности ка украшавању и разметању у име естетске једноставности и чистоте. Супротност укусу доминантне класе јесте 'укус нужности' радничких класа - пољопривредника и радника. Они не поседују ни економски, ни културни капитал, већ се налазе у непрестаној борби са економским и социјалним нужностима које развијају склоности ка ономе што је функционално, неформално, природно и чулно. Између ових супротности налазе се малограђански слојеви које карактерише тежња да се одвоје од радничких класа и да се прикажу као део доминантне класе, али им за то недостаје и капитал и трајне диспозиције (хабитус). Због тога они покушавају да усвоје спољашње знакове животних стилова доминантних класа, приказујући себе као оно што нису" (Бурдије, 2013, 2004).

\section{ПРЕТПОСТАВКЕ}

Основне претпоставке које су водиле ово истраживање јесу: реконструисање типова група туриста које користе услуге туристичких агенција за задовољавање културних потреба путовања у иностранство и њихова партиципација у тој форми културне преференције, као и одређивање њихових социо-демографских корелата.

Претпоставља се да следећа група социјалних фактора обликује културну партиципацију и продукује различите типове културних 
пракси грађана који су користили услуге туристичких агенција: актуелни положај у друштвеној структури, односно услови егзистенције, који су операционализовани кроз образовање и занимање испитаника и кроз њихово место боравка, као и укупни приходи испитаника и њихових породица кроз финансијску могућност/немогућност да путују.

Претпостављена веза између места становања и туристичке потрошње: доминирају испитаници из градског локалитета, а међу њима из Београда. Финансијска успешност је истакнутија у граду, са наглашеним местом у конституисању осећања задовољства у пракси културне потрошње у облику путовања у иностранство.

Претпостављена веза између старости и културне потрошње: битно се разликује пракса путовања у иностранство младих, средовечних и старих испитаника, те су им животна искуства различита; сличности животне доби у којој су доприносе да размишљају о истим темама и истим дестинацијама.

Претпоставили смо да ће се носиоци културне потрошње путовањем у иностранство делити и по учесталости путовања у току једне године: 1 . да путовање у иностранство преко агенција, као културна форма у полупериферијском друштву Србије, неће бити тако често, нарочито међу радницима и пољопривредницима; 2 . да ће учесталије путовање бити карактеристично за доминантне социјалне слојеве (руководиоци, власници и стручњаци); 3. значајан је утицај генерацијског фактора на учесталост путовања; 4. значај територијалних разлика на учесталост путовања; 5. родне разлике нису значајне у пракси путовања.

На основу ставова Бурдијеа, претпостављено је да у друштву Србије постоје три позиције, три типа културних пракси, које приближно одговарају образовним нивоима и професионалним групама, па и њиховој територијалној припадности: 1. Луксузна културна пра$\kappa c a$ - културна пракса слободе, која карактерише више слојеве друштва Србије. Унутар ових група, издваја се доминантна фракција руководиоци и власници, која дугује положај поседовању економског капитала и преферира културну потрошњу путовања коју карактерише хедонизам и лакоћа. У контексту нашег истраживања, преференције би се односиле на веома скупе дестинације које омогућавају максималан хедонизам, уживање. Наклоности луксузног укуса односиле би се на елитне светске дестинације (Куба, Америка, Русија, Африка, Дубаји, Турска); 2. Елитна културна пракса односи се на подређене фракције доминантних слојева (интелектуалци, стручњаци), које положај дугују поседовању културног капитала и склони су аскетској естетици једноставности и чистоте. Ова фракција имала би тенденцију ка елитним културним дестинацијама у иностранству: Шпанија, Италија, Француска, Енглеска; 3. Популарна културна пракса - културна пракса нужности. Овој културној пракси одговара укус нужно- 
сти, који је најприсутнији код радничких класа (пољопривредника и радника). Пољопривредници и радници не поседују ни културни ни материјални капитал, њихов положај састоји се у непрестаној борби са економским и социјалним нужностима, чиме развијају хабитус и склоности ка садржајима који су функционални, неформални, природни, чулни. Наклоност је усмерена ка популарним дестинацијама, које немају уметничке претензије. Дестинације у иностранству које одговарају овом укусу биле би земље региона, а посебно чланице бивше Југославије (,посета рођака и пријатеља"): Црна Гора, Хрватска, Македонија, Бугарска, Мађарска, Румунија. Тиме се покушава показати како се културне потребе, у форми путовања у иностранство, користе као основа за симболичко и социјално искључивање.

Путовање у иностранство преко агенција, као културна форма у полупериферијском друштву, какво је друштво Србије (Благојевић, 2009), функиионише као знак дистинкиије која је отворена само вишим слојевима.

\section{МЕТОД ИСТРАЖИВАҢА}

Основни приступ који је примењен може се одредити као социолошки. Он испитује везу између културне потрошње и кључних друштвених облика груписања: групе према полу, старосне групе, групе према занимању, групе према образовању и групе према материјалним приликама у друштву.

Основни метод овог истраживања јесте анкета. Тестирање постављених хипотеза урађено је на основу непосредне искуствене научне евиденције, добијене из анкетног испитивања у туристичким агенцијама у Друштву Србије. Анкетирање на терену обављено је у периоду март-мај 2014. године. Анкета је спроведена у туристичким агенцијама у Београду и у градовима широм Србије (Лазаревац, Шид, Сремска Митровица, Крушевац, Прокупље, Пирот, Параћин, Јагодина, Ћићевац, Ужице, Шабац, Смедерево, Смедеревска Паланка, Зрењанин, Панчево, Неготин) са грађанима који су се, у време прикупљања података, налазили у агенцији. Извори података су примарни, тј. оригинални извори, који су добијени у натуралистичким, тј. теренским условима.

Рад је заснован на анализи и интерпретацији квантитативних и квалитативних података. За све варијабле израчунаване су фреквенције и урађена потребна укрштања. Осим разматрања особина појединачних варијабли, утврђена је и корелација између варијабли - коефицијент корелације.

\section{Узорак}

Узорак је намерни, квотни узорак, у који су укључени испитаници с обзиром на социо-демографске карактеристике: школска 
спрема, занимање, старост, приходи породичног домаћинства, територијална припадност, пол. Узорак је састављен од укупно 613 испитаника, а од тога градско становништво чинило је 90\%, а сеоско $10 \%$. Родна структура била је у корист жена: $56,9 \%$. Узорак сачињавају пунолетни испитаници који су: а) затечени у туристичкој агенцији у одређеном периоду и б) били спремни да одговарају на питања. У Табели 1 дат је упоредни преглед демографских карактеристика узорка:

Табела 1. Старосна, образовна и професионална структура испитаника

\begin{tabular}{|c|c|c|c|c|c|c|}
\hline \multicolumn{2}{|c|}{ Старост } & \multicolumn{2}{|c|}{ Школска спрема } & Занимање & \multirow[b]{2}{*}{$\Phi$} & \multirow[b]{2}{*}{$\%$} \\
\hline & $\Phi$ & $\%$ & & $\%$ & & \\
\hline $18-30$ & 263 & 42,9 Основна & 16 & 2,6 Политичари & 22 & 3,6 \\
\hline $31-50$ & 241 & 39,3 Средња & 227 & 37,0 Предузетници & 53 & 8,6 \\
\hline $51-65$ & 87 & 14,2 Виша & 98 & 16,0 Самозапослени & 68 & 11,1 \\
\hline 65 и + & 22 & 3,6 Висока & 224 & 36,5 Стручњаци & 163 & 26,6 \\
\hline \multirow[t]{7}{*}{ Укупно } & 613 & $\overline{100,0}$ Магистар & 34 & 5,6 Службеници и техничари & 80 & 13,1 \\
\hline & & Доктор наука & 14 & 2,3 Радници & 29 & 4,7 \\
\hline & & Укупно & 613 & 100,0 Пољопривредници & 6 & 1,0 \\
\hline & & & & Пензионери & 37 & 6,0 \\
\hline & & & & Незапослени & 91 & 14,8 \\
\hline & & & & Студенти & 64 & 10,5 \\
\hline & & & & Укупно & 613 & 100,0 \\
\hline
\end{tabular}

\section{Варијабле}

НЕЗАВИСНА: друштвени положај туриста који путују у иностранство преко туристичких агенција.

ЗАВИСНА: избор дестинације, однос између занимања и праксе путовања, ниво образовања/културног капитала и туристичка пракса, старост и пракса путовања, родне разлике и путовање у иностранство сличности и разлике које у погледу културних потреба путовања у иностранство постоје међу родним, старосним, образовним, професионалним и територијалним групама туриста, које су користиле услуге туристичких агенција.

\section{Операционализаиија варијабли}

У анализу су укључене следеће варијабле, које су релевантне за предмет анализе: доминантна независна социолошка варијабла јесте актуелни положај у друштвеној структури грађана који су користили услуге туристичких агенција у друштву Србије - њихови услови егзистенције, који су операционализовани кроз образовање, занимање и место боравка. Претпоставило се да на обликовање културних пракси утичу још и укупни приходи испитаника и њихових породица: а) високи, средњи, ниски и издржавани (без прихода). На осно- 
ву актуелног положаја испитаника у друштвеној структури, односно њихових услова егзистенције, претпостављене су „високе” друштвене групе у друштву Србије, које су повлашћене у укупној друштвеној структури, која се изражава кроз привилегован материјални положај, тј. ослобођене су од бриге за свакодневну егзистенцију. Насупрот њима стоје „ниске” друштвене групе, које се одликују „културом мањка, немања и одсуства" (Спасић 2013). Укључене су и демографске варијабле, као „тврде” и важне варијабле за ближе одређивање циљева и проверавање постављених хипотеза овог истраживања: 1. старост - млади испитаници од 18 до 30; радно активне старосне групе од 31 до 50 година, старији 51-65, као и стари 65 и више година (претпоставка је да се битно разликује пракса путовања у иностранство младих, средовечних и старих испитаника, као и да су им животна искуства различита; сличности животне доби у којој су доприносе да размишљају о истим темама и истим дестинацијама); 2. објективна варијабла територијалног распореда становништва на релацији село-град. Очекује се да ће културна пракса путовања у градовима, а нарочито у Граду Београду, бити највише заступљена и условљена финансијским успехом испитаника у граду, као и супротности између руралног и урбаног у погледу задовољавања културних потреба путовања; 3. образовање (културни капитал мерен годинама школовањ $а)$; имајући у виду образовни ниво испитаника, разврстали смо их у три групе: оне којима је основна школа највиши степен образовања (без школе, основно образованање, до осам година школовања (8-), испитанике који имају средњу стручну спрему (средње стручне школе и гимназије (12) и оне који су завршили вишу школу и више образовање (факултет, магистратуру/специјализацију, докторат (14+). Старост и културни капитал се у различитим социолошким истраживањима показују као најбитније варијабле - и када је реч о ставовима, и када је реч о социјалној стратификацији, па и у културној потрошњи (Благојевић 2011); 4. Професионалне групе, на основу занимања и радног места, изражене су са пет категорија: руководиоци, власници, стручњаци, службеници, пољопривредници/ радници, пензионери и издржавана лица, чијој припадности смо приписивали ученицима-матурантима, студентима, незапосленима, а који су забележани са $21 \%$ учешћа у узорку. Очекује се да ће, заједно са финансијским успехом, и занимање постати значајно у склопу супротности између руралног и урбаног, пољопривредног и непољопривредног.

\section{РЕЗУЛТАТИ СА ДИСКУСИЈОМ}

У оквиру истраживања културних потреба испитаника, анализиран је садржај слободно-временских активности, при чему је утврђено да је слободно време празно услед: недовољне платежне моћи стано- 
вништва Србије, која се огледа у недостатку новца који би се трошио за задовољавање културних потреба по сопственом нахођењу и жељи (чак 65,1\% таквих изјава), као и недостатка слободног времена (за 11,2\%). Доминирају канали провођења слободног времена који се махом пасивно конзумирају. Активна доколица, изражена у облику задовољавања стваралачких и сазнајних културних потреба, присутна је код четвртине испитаника (23,7\%). Дружење са другим људима, опуштање, учење новог или бављење жељеним активностима у току слободног времена очекивали су се више код испитаника. Изостајање сазнајних и културних интересовања код великог броја испитаника објашњава се економском ситуацијом - недостатком средстава и начина њиховог задовољавања, о чему сведоче испитаници својим одричним одговорима о слободном времену: „немам слободног времена” и „не знам шта је то, стално радим и по три посла у току дана".

\section{Учесталост праксе културне потрошъе у форми путована у иностранство}

Следећи корак ове анализе јесте одређивање основних детерминанти културне потребе за путовање, које су операционализоване на основу изабраних дестинација испитаника у претходним путовањима и учесталости путовања, добијених одговора на два питања: „Када сте последњи пут путовали?” и „Колико пута годишње путујете?”.

Када се врши испитивање учесталости културне потрошње у форми путовања у иностранство, обично се усредсређује на број путовања у иностранство током године. Испитаници су упитани колико су пута путовали у иностранство током године користећи услуге туристичких агенција у периоду од 12 месеци пре анкетирања. Питања су се односила на једно путовање у току године, два, три и више, или на то да испитаници ретко путују. У Табели 2, Табели 3 и Taбели 4 могуће је видети да грађани Србије који путују у иностранство преко агенција путују често. Судећи према изјавама испитаника, сваки пети је рекао да ретко путује (21\%), а да је скоро 4/5 испитаника $(78,2 \%)$ једанпут, два, па и три и више пута путовало у иностранство преко туристичких агенција у годину дана пре анкетирања. Међу онима који учествују у културној потрошњи путовања у иностранство посредством услуга туристичких агенција, могуће је уочити још две групе: ону која једном годишње путује и групу оних који се могу сматрати редовним путницима (два, три и више пута). Групу „једном годишње путујем” чини скоро половина испитаника $(45,7 \%)$, док групама: „два пута” и „три и више” припало је $21,4 \%$ и $11,1 \%$ од свих одговора. Дакле, сваки трећи испитаник партиципира у културној потрошњи путовања у иностранство бар два пута годишње, односно сваки десети чак три и више пута. Ови подаци нису 
једнозначни. Посматрани су међу социјалним групама према занимању и образовању.

Међу социјалним групама постоје јасне разлике у погледу степена учешћа у активностима културне потрошње у форми путовања у иностранство преко туристичких агенција. У понуђеним табелама (Табела 2) могуће је видети како се унутар образовних група структуришу односи оних који посећују и оних који не посећују туристичке агенције ради организовања путовања у иностранство. Ако је претпоставка да је понашање „релевантних других” (Portes, 2000; Putnam, 2000, 1995, Cvetičanin, 2002; 2007: 103), оних са сличним образовањем и професионалним статусом средишња оса што дели праксу културне потрошње међу становништвом које путује у иностранство, онда се у Табели 2 и Табели 3 може видети како се утицај образовања и припадности групама занимања изражава у области туристичке културне потрошње. У групи испитаника чији је највиши степен образовања основна школа има $56,2 \%$ оних који ретко путују у иностранство. Међу високообразованима, на другој страни, учешће група које одлазе једном, два или три и више пута у иностранство у току годину дана пре анкетирања веће је од оних који не одлазе и износи чак $82,5 \%$ : табела 2.

Табела 2. Колико су пута путовали у иностранство у последњих 12 месеии пре анкетирања, унутар образовних група

\begin{tabular}{|c|c|c|c|c|c|c|c|}
\hline \multirow[b]{2}{*}{ Једанпут } & \multicolumn{2}{|c|}{ Осмогодишња } & \multicolumn{2}{|c|}{ Средња } & \multicolumn{2}{|c|}{ Висока } & Укупно \\
\hline & 3 & $1,1 \%$ & 109 & $38,9 \%$ & 168 & $60,0 \%$ & $280 \quad 100,0 \%$ \\
\hline & $18,8 \%$ & & $48,3 \%$ & & $45,3 \%$ & & $45,7 \%$ \\
\hline \multirow[t]{2}{*}{ Два пута } & 2 & $1,6 \%$ & 40 & $30,5 \%$ & 89 & $67,9 \%$ & $131 \quad 100,0 \%$ \\
\hline & $12,5 \%$ & & $17,7 \%$ & & $24,0 \%$ & & $21,4 \%$ \\
\hline \multirow[t]{2}{*}{ Три и више пута } & 2 & $2,9 \%$ & 17 & $25,0 \%$ & 49 & $72,1 \%$ & $68 \quad 100,0 \%$ \\
\hline & $12,5 \%$ & & $7,5 \%$ & & $13,2 \%$ & & $11,1 \%$ \\
\hline \multirow[t]{2}{*}{ Ретко путујем } & 9 & $7,0 \%$ & 57 & $44,2 \%$ & 63 & $48,8 \%$ & $129100,0 \%$ \\
\hline & $56,2 \%$ & & $25,2 \%$ & & $17,0 \%$ & & $21,0 \%$ \\
\hline \multirow[t]{2}{*}{ Непознато } & - & & 3 & $60,0 \%$ & 2 & $40,0 \%$ & $5 \quad 100,0 \%$ \\
\hline & & & $1,3 \%$ & & $0,5 \%$ & & $0,8 \%$ \\
\hline \multirow[t]{2}{*}{ Укупно } & 16 & $2,6 \%$ & 226 & $36,9 \%$ & 371 & $60,5 \%$ & $613100,0 \%$ \\
\hline & $100,0 \%$ & & $100,0 \%$ & & $100,0 \%$ & & $100,0 \%$ \\
\hline
\end{tabular}

На обликовање културног понашања у форми путовања у иностранство посредством услуга туристичких агенција, осим група са сличним образовањем, врше утицај и групе са сличним професионалним статусом. То се види на основу података Табеле 3, који показују да је унутар групе пољопривредника и радника $57,1 \%$ оних који ретко путују у последњих годину дана пре анкетирања. У групи занимања коју чине доминантни социјални слојеви (руководиоци, 
власници и стручњаци), група оних који партиципирају у културној потрошњи у форми путовања у иностранство посредством туристичких агенција већа је и износи 95,5\% код руководилаца, $83,5 \%$ код власника и $86 \%$ код стручњака. У сагласности са овим подацима јесу и вредности Коефицијента контингенције, који је овде висок и износи $\mathrm{c}=0,502$, што значи да постоји статистички значајна веза између варијабли: занимање и учесталост путовања у иностранство, тј. да ће најзначајнији утицај на активности културне потрошње у форми путовања у иностранство имати димензија припадности професионалним групама које су високо плаћене: руководиоци, власници и стручњаци.

Табела 3. Колико су пута путовали у иностранство у последњих 12 месеци пре анкетирања, унутар група занимања

\begin{tabular}{|c|c|c|c|c|c|c|c|c|}
\hline & $\begin{array}{c}\text { Руково- } \\
\text { дилац }\end{array}$ & Власник & Стручњак & $\begin{array}{l}\text { Служ- } \\
\text { беник }\end{array}$ & $\begin{array}{c}\text { Пољо- } \\
\text { при- } \\
\text { вредни } \\
\text { радник }\end{array}$ & $\begin{array}{c}\text { Пензи- } \\
\text { онер }\end{array}$ & $\begin{array}{c}\text { Издржа- } \\
\text { вани }\end{array}$ & Укупно \\
\hline \multirow[t]{3}{*}{ Једанпут } & 8 & 62 & 71 & 41 & 7 & 15 & 76 & 280 \\
\hline & $2,9 \%$ & $22,1 \%$ & $25,4 \%$ & $14,6 \%$ & $2,5 \%$ & $5,4 \%$ & $27,1 \%$ & $100,0 \%$ \\
\hline & $36,4 \%$ & $51,3 \%$ & $43,6 \%$ & $51,3 \%$ & $20,0 \%$ & $40,5 \%$ & $49,0 \%$ & $45,7 \%$ \\
\hline \multirow[t]{3}{*}{ Два пута } & 6 & 26 & 41 & 11 & 6 & 5 & 36 & 131 \\
\hline & $4,6 \%$ & $19,8 \%$ & $31,3 \%$ & $8,4 \%$ & $4,6 \%$ & $3,8 \%$ & $27,5 \%$ & $100,0 \%$ \\
\hline & $27,3 \%$ & $21,5 \%$ & $25,2 \%$ & $13,7 \%$ & $17,1 \%$ & $13,6 \%$ & $23,2 \%$ & $21,4 \%$ \\
\hline Три и & 7 & 13 & 28 & 7 & 1 & 1 & 11 & 68 \\
\hline \multirow[t]{2}{*}{ више } & $10,2 \%$ & $19,1 \%$ & $41,2 \%$ & $10,3 \%$ & $1,5 \%$ & $1,5 \%$ & $16,2 \%$ & $100,0 \%$ \\
\hline & $31,8 \%$ & $10,7 \%$ & $17,2 \%$ & $8,7 \%$ & $2,9 \%$ & $2,7 \%$ & $7,1 \%$ & $11,1 \%$ \\
\hline Ретко & 1 & 20 & 22 & 21 & 20 & 15 & 30 & 129 \\
\hline \multirow[t]{2}{*}{ путује } & $0,8 \%$ & $15,5 \%$ & $17,0 \%$ & $16,3 \%$ & $15,5 \%$ & $11,6 \%$ & $23,3 \%$ & $100,0 \%$ \\
\hline & $4,5 \%$ & $16,5 \%$ & $13,5 \%$ & $26,3 \%$ & $57,1 \%$ & $40,5 \%$ & $19,3 \%$ & $21,0 \%$ \\
\hline \multirow[t]{3}{*}{ Непознато } & - & - & 1 & - & 1 & 1 & 2 & 5 \\
\hline & & & $20,0 \%$ & & $20,0 \%$ & $20,0 \%$ & $40,0 \%$ & $100,0 \%$ \\
\hline & & & $0,5 \%$ & & $2,0 \%$ & $2,7 \%$ & $1,4 \%$ & $0,8 \%$ \\
\hline \multirow[t]{3}{*}{ Укупно } & 22 & 121 & 163 & 80 & 35 & 37 & 155 & 613 \\
\hline & & $19,7 \%$ & $26,6 \%$ & $13,0 \%$ & $5,7 \%$ & $6,1 \%$ & 25,3 & $100,0 \%$ \\
\hline & $100,0 \%$ & $100,0 \%$ & $100,0 \%$ & $100,0 \%$ & $100,0 \%$ & $100,0 \%$ & $100,0 \%$ & $100,0 \%$ \\
\hline
\end{tabular}

Утицај генерацијског фактора на активности културне потрошње на примеру путовања у иностранство посредством туристичких агенција је велики. У случају фреквенције учесталости путовања у иностранство последњих 12 месеци пре анкетирања, може се видети да број и проценат испитаника који путују у иностранство константно опада са порастом година старости, да би у најстаријој генерацији (преко 65 година) било само оних који путују у иностранство једанпут у току последњих 12 месеци пре анкетирања: $39,1 \%$. На другој страни, супротно, чак више од 4/5 младих изјавило је да су 
учествовали у културној потрошњи путовања у иностранство у последњих 12 месеци од анкетирања, а сваки трећи је путовао два, три и више пута у току године $(33,9 \%)$. Ово одступање у корист младих може се објаснити високим уделом „социјалног капитала солидарности" (Coleman, 1988; Halpern, 2005; Cvetičanin and Popescu 2011; Ignjatović, Tomanović, 2011), који се односи на помоћ родитеља и рођака из дијаспоре, али и екскурзије матураната, које су у време анкетирања биле актуелне.

Територијалне разлике између испитаника у погледу степена учешћа у активностима културне потрошње путовања у иностранство су јасне, у сагласности са очекивањима да ће место боравка имати снажан утицај на културну потрошњу путовања, а посебно у погледу утицаја главног града. Унутар просторних група, структуришу се односи оних који ретко путују и оних чије је путовање учестало. Јасно се види како се утицај припадности селу изражава у облику „ретко путујем” - сваки други испитаник, као и да је сваки трећи путовао једном у току последњих 12 месеци од анкетирања $(37,1 \%)$. На другој страни, утицај припадности граду изражава се у облику учесталог путовања, а посебно испитаници Града Београда: $2 / 3$ их је путовало једанпут, више од половине два, три и више пута (56,5\% и 55,9\%).

Родне разлике између испитаника у погледу учесталости путовања у иностранство нису значајније изражене. Тако су жене чешће у групи „ретко путујем” у иностранство $(22,7 \%$, а мушкарци $16,3 \%)$, али и да је скоро свака друга испитаница изјавила да је путовала једном годишње за последњих 12 месеци од анкетирања $(46,8 \%)$. Истовремено, група мушкараца који су путовали у иностранство посредством туристичких агенција бројнија је код учесталих путовања: два, три и више пута - 36\%, а група жена $32 \%$.

У уводном делу истраживања претпостављено је да културна пракса путовања може бити условљена и укупним приходима испитаника и њихових породица кроз финансијску могућност/немогућност да путују. Резултати који су добијени у истраживању о учесталости путовања у погледу финансијског аспекта - јасни су и очекивани. Испитаници су у погледу висине прихода породичног домаћинства подељени у четири групе: оне са високим приходом (чине $15 \%$ узорка), са средњим (чине $46,1 \%$ узорка) и ниским (чине $17,9 \%$ узорка), као и издржавана лица - без прихода (чине $21 \%$ узорка). На основу добијених података о утицају финансијске ситуације испитаника на културну потрошњу у форми путовања у иностранство $(\mathrm{Ta}$ бела 4), издвојиле су се две групе: испитаници са ниским приходом породичног домаћинства који ретко путују - у 39,1\% случајева, на једној страни, и испитаници без прихода - издражавани, чија је културна потрошња у форми путовања у иностранство учестала и неочекивана и зато изазива нејасноћу. Издржавани су учествовали у 
културној потрошњи путовања чак са 79,8\%, што се објашњава „социјалним капиталом солидарности": родитељи и рођаци финансирали су њихово путовање (Cvetičanin and Рорiscu 2011, истичу да је „социјални капитал солидарности” карактеристичан за ниже слојеве, са малом укупном количином капитала). Међу онима са високим приходима, на другој страни, група која често путује у иностранство већа је од оних који „ретко путују” и износи чак $92,4 \%$ - Табела 4. Финансијска ситуација обједињава димензије припадности професионалним и образовним групама, на једној страни, и финансијским могућностима и градског места боравка испитаника, на другој. Путовање у иностранство преко агенција, као културна форма, углавном је отворено за стручњаке, руководиоце/власнике, али и за ученике и студенте, док је учешће пољопривредника и радника мало. Овакви резултати истраживања су очекивани.

Табела 4. Приходи породичног домаћинства испитаника и учесталост путовања

\begin{tabular}{|c|c|c|c|c|c|}
\hline & Високи & Средњи & Ниски & Издржавани & Укупно \\
\hline \multirow[t]{2}{*}{ Једанпут } & $24 \quad 8,6 \%$ & $148 \quad 52,9 \%$ & $44 \quad 15,7 \%$ & $6428,9 \%$ & $280100,0 \%$ \\
\hline & $26,1 \%$ & $24,2 \%$ & $40,0 \%$ & $49,6 \%$ & $45,7 \%$ \\
\hline \multirow[t]{2}{*}{ Два пута } & $3123,7 \%$ & $56 \quad 42,7 \%$ & $118,4 \%$ & $3325,2 \%$ & $131 \quad 100,0 \%$ \\
\hline & $33,7 \%$ & $19,9 \%$ & $10,0 \%$ & $25,6 \%$ & $21,4 \%$ \\
\hline \multirow[t]{2}{*}{ Три и више } & $30 \quad 44,1 \%$ & $22 \quad 32,4 \%$ & $10 \quad 14,7 \%$ & $6 \quad 8,8 \%$ & $68 \quad 100,0 \%$ \\
\hline & $32,6 \%$ & $7,8 \%$ & $9,1 \%$ & $4,6 \%$ & $11,1 \%$ \\
\hline \multirow{4}{*}{$\begin{array}{l}\text { Ретко } \\
\text { путује } \\
\text { Непознато }\end{array}$} & $6 \quad 4,7 \%$ & $56 \quad 43,4 \%$ & $43 \quad 33,3 \%$ & $24 \quad 18,6 \%$ & $129100,0 \%$ \\
\hline & $6,5 \%$ & $19,9 \%$ & $39,1 \%$ & $18,6 \%$ & 21,0 \\
\hline & $120,0 \%$ & - & $240,0 \%$ & $240,0 \%$ & $5 \quad 100,0 \%$ \\
\hline & $1,1 \%$ & & $1,8 \%$ & $1,5 \%$ & $0,8 \%$ \\
\hline \multirow[t]{2}{*}{ Укупно } & $92 \quad 15,0 \%$ & $28246,1 \%$ & $110 \quad 17,9 \%$ & $12921,0 \%$ & $613100,0 \%$ \\
\hline & $100,0 \%$ & $100,0 \%$ & $100,0 \%$ & $100,0 \%$ & $100,0 \%$ \\
\hline
\end{tabular}

\section{СЕГМЕНТАЦИЈА ИСПИТАНИКА ПРЕМА ОБЛИЦИМА КУЛТУРНЕ ПОТРОШЬЕ}

Ослањајући се на претходну анализу, извршена је сегментација испитаника према облицима културне потрошње, а на основу избора жељене дестинације. Такође, следећи Бурдије, које је дато у оквиру хипотеза, покушали смо да бурдијеовски појам дистинкције применимо на искуствену грађу путовања у иностранство. У којој мери се може говорити о присуству „дистинктивних културних стратегија" (Спасић 2013) у културној пракси путовања у иностранство избор скупе и далеке дестинације као симболичко средство доминантних слојева, стратегија је дистинкција, и то дистинкција културе (Спасић 2013: 49, 50) - како би се успоставила властита супериор- 
ност избором дестинације. На основу ових ставова, претпостављено је да у узорку постоје три позиције, три стратегије избора дестинациjа, три типа културних пракси, које приближно одговарају образовним нивоима испитаника и професионалним групама, па и њиховој територијалној припадности: 1. Луксузна културна пракса - која карактерише више слојеве друштва Србије (доминантна фракција руководиоци и власници, која положај дугује поседовању економског капитала), чини 12,2\% узорка; 2. Елитна културна пракса, коју представља фракција образовних стручњака, који положај дугују поседовању културног капитала и чини $30 \%$ узорка и 3 . Популарна културна пракса - културна пракса нужности (путовање у земље региона), која је најприсутнија код радничких класа (пољопривредника и радника) и код пензионера - чини 57,1\% узорка: Табела 5 и Табела 6.

Табела 5. Диферениијалне културне праксе, унутар група занимања

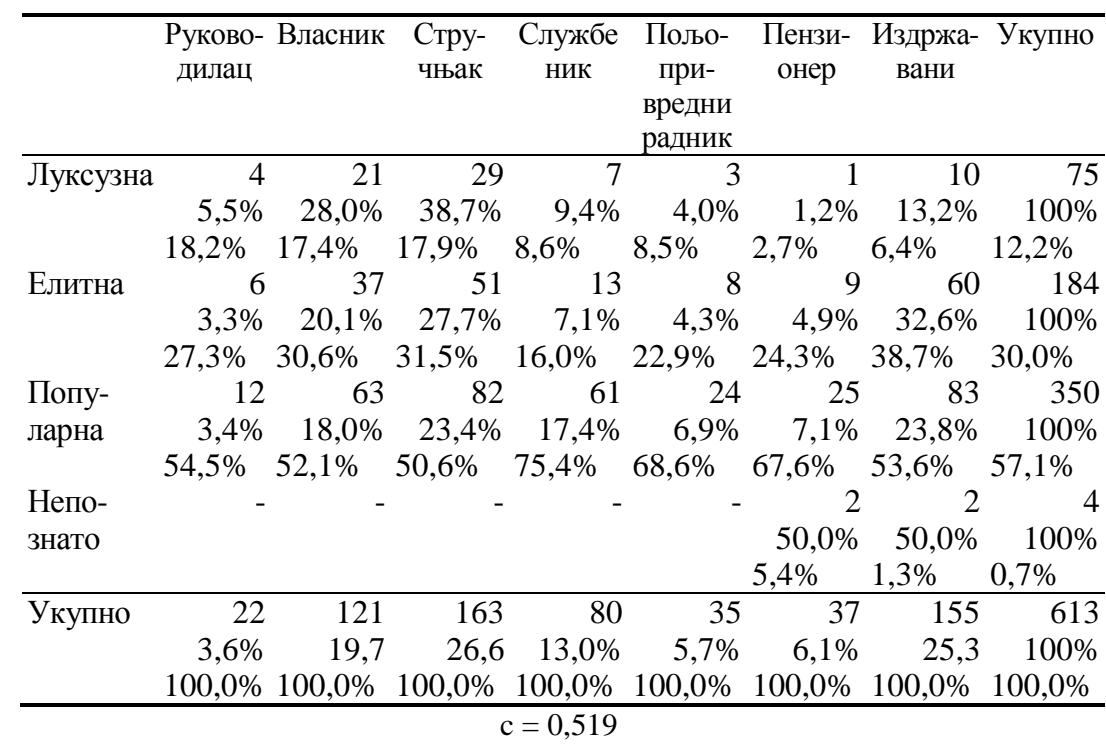

Групе руководилаца, власника и стручњака употребљавају културну потрошњу у форми путовања у иностранство да подигну „симболичке препреке” (Цветичанин, 2007: 32) између њих и оних социјалних група које су им поларизоване на лествици друштвене хијерархије, пошто су за њих луксузне и елитне дестинације биле највише отворене. Културна потреба путовања у иностранство користи се као основа за симболичко и социјално искључивање. Подаци Табеле 5 показују да су пољопривредници и радници (4\%), као и пензионери $(1,1 \%)$ скоро искључени из луксузних и елитних дестинација. 
Табела 6. Диферениијалне културне праксе, унутар група образовања

\begin{tabular}{|c|c|c|c|c|c|}
\hline & Осмого & дишња & Средња & Висока & Укупно \\
\hline \multirow[t]{2}{*}{ Луксузна } & 1 & $1,3 \%$ & $1722,7 \%$ & $5776,0 \%$ & $75 \quad 100,0 \%$ \\
\hline & $6,3 \%$ & & $7,5 \%$ & $15,4 \%$ & $12,2 \%$ \\
\hline \multirow[t]{2}{*}{ Елитна } & 6 & $3,3 \%$ & $7440,2 \%$ & $10456,5 \%$ & $184100,0 \%$ \\
\hline & $37,4 \%$ & & $32,6 \%$ & $28,1 \%$ & $30,0 \%$ \\
\hline \multirow[t]{2}{*}{ Популарна } & 8 & $2,3 \%$ & $13338,0 \%$ & $20959,7 \%$ & $350 \quad 100,0 \%$ \\
\hline & $50,0 \%$ & & $58,6 \%$ & $56,5 \%$ & $57,1 \%$ \\
\hline \multirow[t]{2}{*}{ Непознато } & 1 & $25,0 \%$ & $375,0 \%$ & - & $4100,0 \%$ \\
\hline & $6,3 \%$ & & $1,3 \%$ & & $0,7 \%$ \\
\hline \multirow[t]{2}{*}{ Укупно } & 16 & $2,6 \%$ & $22636,9 \%$ & $37160,5 \%$ & $613100,0 \%$ \\
\hline & $100,0 \%$ & & $100,0 \%$ & $100,0 \%$ & $100,0 \%$ \\
\hline
\end{tabular}

Сегментација испитаника на основу избора дестинације, према школској спреми и занимању (Табела 5 и Табела 6) - такође потврђује полазну хипотезу да је културна пракса путовања у иностранство изразито „хијерархијско поље”. Луксузне и скупе културне праксе путовања у иностранство отворене су носиоцима високог образовања, чак у више од $3 / 4$ корисника услуга туристичких агенција (76\%) Табела 6. У прилог томе иде и висока вредност Коефицијента контингенције $(c=0,538)$, који казује да је јака веза између варијабли: висина културног капитала и избора луксузних и скупих дестинација у културној потрошњи путовања у иностранство, односно да је уживање у високој форми културне потрошње путовања у иностранство постало ознака високих слојева: Табела 5 и Табела 6. Бурдијеова концепција помогла је да се разуме улога културних ресурса у репродукцији групних неједнакости у друштву Србије, као и да је прилагођавање културним праксама ,релевантних других” и дистанцирање од других, повлачење културних граница које су „хијерархијске и вреднујуће" (Спасић, 2013: 32).

Истовремено, употребљивост Бурдијеове концепције или бурдијеовско ишчитавање грађе о разликовању два основна типа стила живота доминантне и подређене фракције владајуће класе на примеру луксузне и елитне диференцијалне културне праксе путовања у иностранство - нема смисла у предоченој грађи Табеле 5. Тако је приврженост луксузној и елитној културној пракси код доминантне фракције руководиоци и власници и подређене фракције доминантних слојева интелектуалци и стручњаци - скоро подједнако заступљена (17,5\% у поређењу са $17,9 \%$ и $30,1 \%$ у односу са 31,5 посто): Табела 5. Ово одступање од очекивања - нејасна разлика између луксузне културне праксе и елитне културне праксе доминантне и подређене фракције владајуће класе објашњава се чињеницом да залагања нису увек међусобно искључива: стручњаци се залажу за вредновање образовања и културе, а предузетници за пословну способ- 
ност. Али, пословна способност није супротна култури: способност да се нешто створи или да се успешно руководи спајају се у један уопштени „квалитет човека” (Спасић 2013: 86). Има руководилаца и власника који и те како инсистирају на култури и културној потрошњи у форми путовања у иностранство ради посете луксузних и елитних дестинација, прихватајући тиме избор дистинкције.

\section{ЗАКЉУЧАК}

У овом истраживању намера је била да се анализира посебан облик културне потрошње на примеру путовања у иностранство, уз ослонац на Бурдијеово теоријско становиште о томе како култура и културна потрошња доприносе репродукцији система у савременим друштвима. Социолошки приступ проблему путовања у иностранство као облика културне потрошње, који је дат у овом истраживању, показао је да путовање у иностранство преко агенција функционише као знак дистинкције која је отворена само вишим слојевима - „релевантних других”, оних са сличним образовањем и професионалним статусом.

Резултати истраживања су показали да се утицај образовања и припадности групама занимања изражава у области туристичке културне потрошње. Они са основном школом ретко путују, док је учешће група које одлазе у иностанство једанпут, два, три и више пута на годину дана у корист високообразованих, као и групе занимања: руководилаца, власника и стручњака.

Утицај генерацијског фактора на учесталост путовања у иностранство је велики. Такође, јасне су и територијалне разлике између испитаника у погледу степена учешћа у активностима културне потрошње путовања у иностранство: припадност селу се изражава у облику „ретко путујем”, а утицај припадности граду се изражава у облику учесталог путовања, а посебно испитаници Града Београда. Родне разлике између испитаника у погледу учесталости путовања нису значајније изражене.

Финансијска ситуација обједињава димензије припадности професионалним и образовним групама на једној страни, те финансијским могућностима и градског места боравка испитаника, на другој страни. Путовање у иностранство преко агенција, као културна форма, углавном је отворена за стручњаке, руководиоце/власнике, али и за ученике и студенте, док је учешће пољопривредника и радника мало. Издржавани су учестало путовали захваљујући „социјалном капиталу солидарности".

Потврдило се да путовање у иностранство преко агенција, као културна форма у полупериферијском друштву, какво је друштво Србије, функционише као знак дистинкције која је отворена само ви- 
шим слојевима како би се успоставила властита супериорност избором дестинације.

Творци политике путовања - културна потрошња путовањем у иностранство, на нивоу глобалног друштва, области или општина, као и туристичких организација, могу задовољити своје интересовање резултатима овог истраживања у погледу објашњења узрока културне праксе путовања у иностранство и његове функције у друштву или за појединце. Творци културне политике могу из овог истраживања видети да је у њему извршена идентификација културних група у друштву Србије које користе услуге туристичких агенција за путовање у иностранство (на основу сличности њихових културних потреба) и њихова дистрибуција међу образовним, професионалним и територијалним групама, као и међу родним и старосним обележјима.

\section{ЛИТЕРАТУРА}

Благојевић Хјусон, Марина. 2011. Жене и мушкарци у Србији: ита нам говоре бројеви? [Women and Men in Serbia: What do the Numbers Tell us?]. Програм Уједињених нација за развој, Београд.

Blagojević, Marina. 2009. Knowledge Production at the Semiperiphery: A Gender Perspective, Belgrade: Institut za kriminološka i sociološka istraživanja.

Božović R., Ratko (1991). Kultura potreba [The Culture of Needs], Beograd: Naučna knjiga.

Burdije, Pjer. 2013. Distinkcija: društvena kritika suda [Distinction: A Social Critique of the Judgement of Taste], Podgorica, CID

Burdije, P. 2004. „Habitus i prostor stilova života” [The Habitus and Space of Lifestyles], U: Kultura, br.109/112, Beograd, str. 131-170.

Burdije, Pjer. 1999. Nacrt za jednu teoriju prakse [Outline of a Theory of Practice], Beograd: Zavod za udžbenike i nastavna sredstva.

Bourdieu, Pierre (1984). Distinction. A Social Critique of the Judgement of Taste, Harvard University Press, Cambridge USA.

Bourdieu, P. (1985). The forms of capital, in: Richardson, J.G. (Ed.). Handbook of Theory and Research for the Sociology of Education. New York: Greendwood.

Cvetičanin, Predrag and Mihaela Popiscu. 2011. „The art of making classes in Serbia: Another particular case of the possible", Poetics 39 (6), str. 444-468.

Cvetičanin, Predrag. 2007. Kulturne potrebe, navike i ukus građana Srbije [Cultural Needs, Habits and Taste of the Serbian Citizens]. Niš: Odbor za građansku inicijativu.

Cvetičanin, Predrag (2002): „Kulturne potrebe, navike i ukus građana Srbije” [Cultural Needs, Habits and Taste of the Serbian Citizens], OGI/Pro Helvetia.

Coleman, J. (1988). Social capital in the creation of human capital. The American Journal of Sociology.

Dragićević-Šešić, Milena (1983). Turističke potrebe kao kulturne potrebe [Tourism Needs as Cultural Needs]. U: Časopis „Kultura”, Zavod za proučavanje kulturnog razvitka, Beograd.

Čolić, S. (2008) Sociokulturni aspekti potrošnje, potrošačke kulture i društva [Sociocultural Aspects of Consumption, Consumer Culture and Society], Društvena istraživanja, 17/6; 953-973.

Halpern, D. (2005). Social Capital. Cambridge: Polity Press. 
Ignjatović, S. i Tomanović, S. (2011). „Socijalni kapital i prostor” [Social Capital and Space], u: Sociologija i prostor, 49 (2011) 191 (3): 269-286.

Košničar, Sofija (1999): „Kulturne potrebe i ponašanja stanovnika Srbije (I, III)” [Cultural Needs and Behaviour of the Serbian Citizens], u: Zbornik Matice srpske za društvene nauke, br. 104-105, str. 89-108, Novi Sad.

Portes, A. (2000). The Two Meanings of Social Capital. Sociological Forum, 15 (1): 1-12. Putnam, R.D. (1995). Bowling alone revisited. The Responsive Community, 5 (2): 18-33.

Putnam, R.D. (2000). Bowling Alone. New York: Simon and Schuster Paperbacks.

Spasić, Ivana. 2013. Kultura na delu. Društvena transformacija Srbije iz burdijeovske perspektive [Culture in Action. Social transformation of Serbia from Bourdieu's Perspective], Beograd: Edicija REČ.

\title{
TRAVEL ABROAD AS A FORM OF CULTURAL CONSUMPTION IN SERBIAN SOCIETY
}

\author{
Ljubica M Rajković \\ University of Belgrade, Faculty of Geography, Belgrade, Serbia
}

\begin{abstract}
Summary
The results of the sociological research on the topic of travelling abroad as a form of cultural consumption in the Serbian society, based on Bourdieu's theoretical standpoint on how culture and cultural consumption contribute to reproduction of systems in contemporary societies, have shown that travelling abroad through travel agencies presents a sign of distinction that is affordable only to higher classes - those with similar education and professional status. The influence of education and belonging to occupational groups is evident in the field of cultural tourism consumption. Thus, individuals with primary school education rarely travel, while groups that travel abroad, once, twice, three or more times a year consist of highly educated individuals and of those belonging to the following occupations: managers, company owners and professionals. The influence of the generation factor on the frequency of travelling abroad is also significant. Also, there are clear territorial differences between the respondents regarding the level of participation in cultural tourism i.e. travelling abroad: rural dwellers have answered mostly "rarely travel", whereas urban dwellers have answered that they travel frequently, in particular the respondents from the City of Belgrade. Gender differences among the respondents regarding the frequency of travel are not significant. The financial situation combines the dimensions of belonging to professional and educational groups on one side, while the financial means and urban residence of the respondents are combined on the other. Travelling abroad through travel agencies, as a cultural form in a semi-peripheral society, such as the Serbian society, is mainly affordable to professionals, managers/company owners, but also for pupils and students, while participation of farmers and blue-collar workers is negligible and functions as a sign of distinction that is affordable only to higher layers of society, especially in order to establish one's own superiority through the choice of destinations. The dependent respondents travelled frequently owing to the "solidarity as social capital".
\end{abstract}

